\title{
Углеродные ультрадисперсные частицы из древесины бамбука для модифицирования полимерных композитов
}

\section{Ultra dispersed carbon particles made from bamboo aimed for modification of polymer matrix composites}

\section{Л. Р. Вишняков, Е. Л. Вишнякова}

Научно-производственный центр

«Углеродные волокна и композиты» г. Мытищи, Россия

\section{До Дык Хуэн}

Наблюдательный Совет/Хай -Тек Парк,

Министерство Науки и Технологии, г. Ханой, Вьетнам

Поступила в редакцию 28.01.2021, принята кпечати 04.02.2021
L. R. Vishnyakov, E. L. Vishnyakova

UVICOM Co Ltd.

Carbon Fibres and Composites

\section{Do Dyck Huen}

HighTech Park, Ministry of Science and Technology of Vietnam, Hanoi

\section{Абстракт}

Рассмотрены особенности получения углеродных ультрадисперсных частиц в процессах пиролиза и карбонизации древесины бамбука. Установлено влияние размола (аттрирования) стружки бамбука и обработки катализаторами на электросопротивление продукта. Приведена методика измерения электросопротивления наноструктурных частиц углерода. Показано, что модифицирование полимерного диэлектрического связующего ультрадисперсными частицами углерода, полученного из древесины бамбука, увеличивает его электропроводность и может быть использовано в композитах с полимерной матрицей.

\section{Abstract}

The features of obtaining carbon ultrafine particles in the processes of pyrolysis and carbonization of bamboo wood are considered. An effect of grinding of bamboo shavings and treatment with catalysts on the electrical resistance of the product has been established. A technique for measuring the electrical resistance of nanostructured carbon particles is described. It is shown that modification of dielectric polymers by ultra-dispersed carbon particles increases its electrical conductivity that can be used in polymer matrix composites.

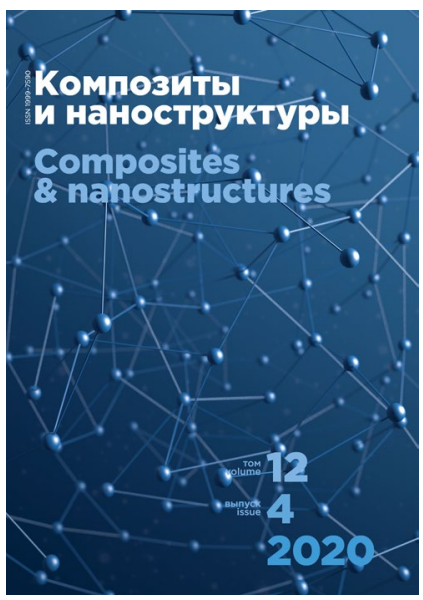

